Journal of Education and Teaching Learning (JETL) 2019

Vol. 1, No. 2, 9-18

Journal Homepage: http://pusdikra-publishing.com/index.php/jetl

\title{
MENINGKATKAN HASIL BELAJAR MATEMATIKA SISWA TENTANG LUAS BANGUN DATAR MELALUI PENDEKATAN KONTEKSTUAL DI KELAS V SD NEGERI 101880 TANJUNG MORAWA
}

\author{
Arniati Manalu*)
}

\begin{abstract}
Abstrak
Penelitian ini dilakukan untuk mengetahui peningkatan hasil belajar, hasil belajar afektif, dan hasil belajar psikomotorik siswa pada pembelajaran Matematika tentang Luas Bangun Datar melalui pendekatan kontekstual di kelas Kelas V SD Negeri 101880 Tanjung Morawa. Subjek dalam penelitian ini adalah siswa kelas Kelas V SD Negeri 101880 Tanjung Morawa sebanyak 28 orang, terdiri dari 18 siswa laki-laki dan 10 siswa perempuan. Teknik pengupulan data dilakukan secara kuantitatif dan kualitatif dengan menggunakan tes tentang Luas Bangun Datar, angket belajar afektif, dan belajar psikomotorik siswa. Selain itu, dilakukan juga obeservasi terhadap guru tentang pelaksanaan kegiatan pembelajaran. Hasil dari penelitian ini adalah (1) terjadi peningktan hasil belajar siswa Kelas V SD Negeri 101880 Tanjung Morawa tentang Luas Bangun Datar melalui pendekatan kontekstual. Nilai rata-rata kelas mengalami peningkatan dari 60,71 pada siklus I menjadi 79,96 pada siklus II, sedangkan ketuntasan kelas mengalami peningkatan dari $60,71 \%$ pada siklus I dan menjadi $85,71 \%$ pada siklus II; (2) hasil belajar afektif siswa Kelas V SD Negeri 101880 Tanjung Morawa terhadap pembelajaran tentang Luas Bangun Datar melalui pendekatan kontekstual adalah baik dan mengalami peningkatan dari $78,97 \%$ pada siklus I menjadi $89,28 \%$ pada siklus II. Hal tersebut menunjukkan siswa bersikap baik dan memiliki minat yang tinggi terhadap pembelajaran, dan ; (3) hasil belajar psikomotorik siswa Kelas V SD Negeri 101880 Tanjung Morawa tentang Luas Bangun Datar melalui pendekatan kontekstual juga mengalami peningkatan dari $85,71 \%$ pada silkus I menjadi $96,42 \%$ pada siklus II. Hal tersebut menunjukkan siswa sangat aktif mengikuti pembelajaran tentang Luas Bangun Datar.
\end{abstract}

Kata kunci : hasil belajar,dan pendekatan kontekstual

\section{PENDAHULUAN}

Matematika merupakan salah satu mata pelajaran penting bagi siswa.Matematika juga merupakan ilmu dasar yang harus dikuasai siswa.Matematika sangat terkait dengan kehidupan seharihari, oleh sebab itu siswa kelas I Sekolah Dasar (SD) sudah diperkenalkan dengan Matematika.

Bagi sebagian siswa Matematika merupakan pelajaran yang sangat sulit dan sangat membosankan. Hal tersebut dikarenakan Matematika terkait dengan perhitungan-perhitungan yang rumit, serta beberapa objek Matematika bersifat abstrak. Beberapa hal tersebut yang membuat sebagian siswa merasa kesulitan dalam menguasai materi pemlejarajan Matematika.

Meskipun demikian siswa tidak dapat menghindari Matematika. Siswa dituntut untuk mampu menguasai materi-materi Matematika, agar tidak kesulitan dalam memecahkan permasalahan dalam kehidupan seha-hari.

\footnotetext{
*) Penulis adalah guru SD NEGERI 101880 Tanjung Morawa
} 
Namun, menurut pengamatan peneliti selama mengajar di Kelas V SD Negeri 101880 Tanjung Morawa hasil belajar siswa kelas I tentang Luas Bangun Datar masih sangat rendah. Hal itu didasarkan pada sebagian besar nilai Ulangan Harian (UH) siswa kelas V masih dibawah Kriteria Ketuntasan Minimal (KKM) yaitu 65.

Bila ditelusuri lebih lanjut rendahnya hasil belajar siswa tentang Luas Bangun Datar disebabkan guru tidak menggunakan media pembelajaran yang akan memudahkan siswa memahami hal-hal yang masih abstrak menjadi lebih konkrit. Selain itu, guru hanya melakukan kegiatan pembelajaran secara konvensional, tidak menggunakan pendekatan pembelajaran yang tepat.

Dampak rendahnya hasil belajar siswa tentang Luas Bangun Datar jika tidak segera diberi penyelesaian yang tepat adalah rendahnya perolehan nilai rapor semester satu siswa pada mata pelajaran Matematika,selain itu siswa juga akan mengalami kesulitan memahami materi-materi Matematika berikutnya yang masih berkaitan dengan materi Luas Bangun Datar.

Berdasarkan uraian di atas, maka peneliti tertarik untuk melakukan Penelitian Tindakan Kelas (PTK) dengan judul "Meningkatkan Hasil Belajar Matematika Siswa tentang Luas Bangun Datar Melalui Pendekatan Kontekstual di Kelas V SD Negeri 101880 Tanjung Morawa".

\section{A. Hasil Belajar Matematika}

Hasil belajar menurut Dimyati (2006:12) adalah hasil proses belajar di mana pelaku aktifdalam belajar adalah siswa dan pelaku aktif dalam pembelajaran adalahguru. Selain itu, Sudjana (2005:3) hasil belajar adalah perubahan tingkah laku siswa setelah melalui proses pembelajaran. Sejalan dengan itu, Anni (2007:5) menyatakan bahwa hasil belajar merupakan perubahan perilaku yang diperoleh siswa setelah mengalami aktivitas belajar. Selain itu, Depdikbud (1995:343) hasil belajar adalah sesuatu yang diadakan oleh usaha. Sementara itu, Rahayu (2013:122) menyatakan hasil belajar adalah tingkat keberhasilan dalam menguasai pelajaran setelah memperoleh pengalaman atau proses belajar mengajar dalam kurun waktu tertentu yang akan diperlihatkan melalui skor yang diperoleh dalam tes hasil belajar.

Hasil belajar dalam penelitian ini adalah hasil belajar siswa melalui proses pembelajaran menemukan fakta dan konsep yang dapat diukur melalui tes hasil belajar matematika dalam materi Luas Bangun Datar.

\section{B. Pendekatan Kontekstual}

Nurhadi (2003: 13) menyatakan pendekatan kontekstual adalah konsep belajar dimana gurumenghadirkan dunia nyata kedalam kelas dan mendorong siswa membuathubungan antara pengetahuan yang dimilikinya dengan penerapannya dalamkehidupan mereka sehari-hari, sementara siswa memperoleh pengetahuan danketerampilan dari konteks yang terbatas, sedikit demi sedikit, dan 
dari prosesmengkontruksi sendiri, sebagai bekal untuk memecahkan masalah dalamkehidupannya sebagai anggota masyarakat.Menurut Andayani (2009:4),

pendekatan kontekstual merupakan pembelajaran yang menghubungkan antara materi yang diajarkan dengan dunia nyata, selain ituterdapat ciri penanda bahwa pendekatan kontekstual dapat mendorong siswa membuat hubunganantara pengetahuan yang dimilikinya dengan dunia nyata. Selain itu, Sanjaya (2007:253) mengungkapkan pendekatan kontekstual adalah strategi pembelajaran yang menekankankepada proses keterlibatan siswa secara penuh untuk dapat menemukan materi yang dipelajari dan menghubungkannya dengan situasi kehidupan nyatasehingga mendorong siswa untuk dapat menerapkannya dalam kehidupanmereka.

Sedangkan menurut Suminarsih dalam Natamia (2009:49),pendekatan kontekstual adalah konsep belajar yang membantu gurumengaitkan antara materi yang diajarkan dengan situasi dunia nyata siswa danmendorong siswa membuat hubungan antara pengetahuan yang dimilikidengan penerapannya dalam kehidupan sehari-hari.

Dari uraian di atas dapat peneliti menyimpulkan bahwa pendekatan kontekstual merupakan suatu pendekatan pembelajaran yang membantu guru dalam mengaitkan bahan ajarnya dengan situasi dunia nyata siswa dan mendorong siswa membuat hubunganantara pengetahuan yang dimilikinya dengan penerapannya dalam kehidupan sehari-hari.

\section{METODOLOGI PENELITIAN}

\section{A. Objek Penelitian}

Objek penelitian ini adalah melalui pendekatan kontekstual dapat meningkatkan hasil belajar siswa tentang Luas Bangun Datar.

\section{B. Setting/Lokasi/Subjek Penelitian}

Penelitian ini dilakukan di SD Negeri 101880 Tanjung Morawa Kecamatan Tanjung Morawa Kabupaten Deli Serdang.

Subjek pada penelitian ini adalah siswa kelas $\mathrm{V}$ berjumlah 28 orang, yang terdiri dari 18 orang laki-laki dan 10 orang perempuan.

\section{Deskripsi Setiap Siklus}

Penelitian ini dilakukan selama 2 siklus, mekanisme penelitian dalam pembelajaran adalah hasil belajar siswa melalui pendekatan kontekstual pada materi tentang Luas Bangun Datar.Adapun tahap-tahap yang dilakukan dalam penelitian ini, meliputi (1) rencana tindakan, (2)pelaksanakan tindakan, (3) observasi dan evaluasi, dan (4) analisis dan refleksi.

Tahapan-tahapan tersebut seperti pada gambar di bawah ini. 


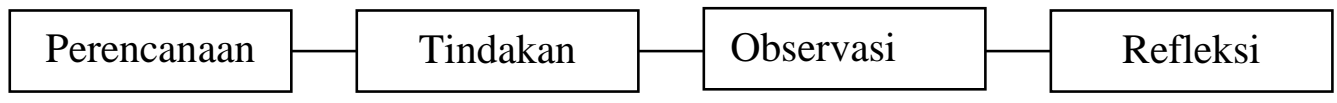

\section{Gambar 3.1 Prosedur pelaksanaan PTK}

Penelitian Tindakan Kelas ini pelaksanaanya mengikuti alur sebagai berikut.

\section{Perencanaan}

Pada tahap ini dilakukan diskusi dengan teman sejawat untuk menyusun perencanaan yang akan digunakan dalam tindakan.Perencanaan yang dipersiapkan seperti: menyusun Rencana Pelaksanaan Pempelajaran (RPP), mendesain ruang kelas,membuat lembar observasi afektif dan psikomotorik siswa,lembar observasi untuk guru dan mempersiapkan bahan ajar, serta mempersiapkan perangkat tes serta instrumennya.

Selanjutnya peneliti,melakukan validasi perangkat pembelajaran yang akan digunakan yaitu: RPP dan instrumen tes tentang Luas Bangun Datar. Validitas dilakukan dengan meminta pendapat ahli menyangkut isi, bahasa, dan kesesuaian perangkat pembelajaran dengan pembelajaran, kebaikan dan kelemahan perangkat, dan memberikan saran perbaikan. Selanjutnya, pendapat ahli dikuantifikasikan yang kemudian diskor dengan cara-cara tertentu.

Sebelum tindakan dilakukan, peneliti juga berdiskusi dengan pengamat untuk membentuk kelompok diskusi siswa yang heterogen dalam pembelajaran. Kelompok heterogen yang dibentuk dengan mempertimbangkan: prestasi belajar, jenis kelamin, suku dan agama, sosial ekonomi, kecocokan diantara siswa, dan hal-hal lain yang mempengaruhi agar diskusi kelompok berjalan lancar. Setelah seluruh persiapan terpenuhi maka peneliti dan pengamat bersama-sama melaksanakan tugasnya masing-masing.

\section{Tindakan}

Pada tahap tindakan ini, peneliti melakukan tindakan di kelas dengan menerapkan pembelajaran tentang Luas Bangun Datar berdasarkan seluruh perencanaan pembelajaran yang telah dibuat pada tahap awal (perencanaan). Sebelumnya dua orang teman sejawat telah ditunjuk untuk bertindak sebagai pengamat yang bertugas mencatat semua kejadian yang terjadi pada saat tindakan berlangsung dengan sejujur-jujurnya. Hal-hal yang menjadi pusat perhatian pengamat adalah dimulai dari aktivitas guru dan aktivitas siswa, dan hal-hal lain yang mungkin timbul di dalam kelas pada saat tindakan berlangsung.

Skor yang diberikan untuk kemampuan guru dalam mengelola pembelajaran antara 1 sampai 4 untuk setiap indikator penilaian. Skor 1 berarti kurang, skor 2 berarti cukup, skor 3 berarti baik, dan skor 4 berarti sangat baik dalam melakukan aktivitas atau indikator pada setiap kegiatan pembelajaran. 


\section{Observasi (Observation)}

Tahapan ini dilakukan pada saat tindakan berlangsung, observer menggunakan lembar observasi aktivitas (afektif dan psikomotorik) siswa dan guru yang telah dibuat sebelumnya. Lembar observasi ada dua yaitu lembar observasi untuk aktivitas guru dalam mengelola pembelajaran tentang menentukan Luas Bangun Datar melalui pendekatan kontekstual dan lembar observasi untuk aktivitas siswa selama pembelajaran.Pengamatan terhadap guru meliputi: aktivitas guru dalam mengelola pembelajaran, kegiatan guru pada kegiatan awal pembelajaran, kegiatan inti, dan kegiatan akhir pembelajaran. Sedangkan pengamatan terhadap aktivitas siswa meliputi: keaktifan dalam kelompok, sikap dalam belajar, keaktifan menyelesaikan tugas, dan kemampuan dalam menentukan Luas Bangun Datar. Selain menggunakan lembar observasi, pengamat dan peneliti juga menggunakan catatan lapangan.

Observasi dan evaluasi dilaksanakan bersamaan dengan proses pembelajaran, meliputi pengamatan terhadap kegiatan guru, kegiatan siswa dalam melaksanakan diskusi kelompok, dan hasil belajar siswa dalam menyelesaikan soal tentang Luas Bangun Datar. Observasi dilakukan oleh peneliti sendiri dengan mengamati proses dan hasil belajar siswa dengan menggunakan lembar observasi yang telah dibuat olehpeneliti.

Observasi adalah pengamatan langsung yang dilakukan peneliti untuk memperoleh data berupa afektif dan psikomotorik siswa selama pembelajaran dan kemampuan guru mengelola pembelajaran. Pengamatan dilakukan dengan mencatat secara sistematik kejadian-kejadian, perilaku dan hal-hal lain yang timbul pada saat pembelajaran berlangsung.

\section{a) Observasi terhadap aspek afektif siswa}

Lembar pengamatan siswa berisi tentang aspek afektif siswa selama pembelajaran berlangsung. Dalam penelitian ini hasil pengamatan dilakukan dengan memberikan skor menurut skala yang telah ditentukan. Skor yang diberikan antara 1 sampai 4 . Skor 1 berarti kurang, skor 2 berarti cukup, skor 3 berarti baik, dan skor 4 berati sangat baik

\section{b) Observasi terhadap aspek psikomotorik siswa}

Lembar pengamatan siswa berisi tentang aspek psikomotorik siswa selama pembelajaran berlangsung. Dalam penelitian ini hasil pengamatan dilakukan dengan memberikan skor menurut skala yang telah ditentukan. Skor yang diberikan antara 1 sampai 4 . Skor 1 berarti kurang, skor 2 berarti cukup, skor 3 berarti baik, dan skor 4 berati sangat baik.

\section{c) Observasi Kemampuan Guru Mengelola Pembelajaran}

Lembar obsevasi (pengamatan) untuk peneliti yang telah disediakan oleh peneliti harus diisi oleh pengamat dengan sejujur-jujurnya agar penelitian ini mendapat hasil yang baik. Lembar pengamatan guru ini berisikan segala aktivitas guru mengelola pembelajaran baik yang sesuai ataupun 
yang belum sesuai harus dituliskan untuk dijadikan sebagai pedoman dari penelitian ini. Dalam penulisan hasil pengamatan ditulis dengan penulis memberikan skor menurut skala yang telah ditentukan.

Skor yang diberikan untuk kemampuan guru dalam mengelola pembelajaran antara 1 sampai 4 untuk setiap indikator penilaian. Skor 1 berarti tidak pernah, skor 2 berarti jarang, skor 3 berarti sering, dan skor 4 berarti selalu dalam melakukan aktivitas atau indikator pada setiap kegiatan pembelajaran.

\section{Refleksi (Reflection)}

\section{a. Siklus I}

Tahapan ini dilakukan setelah tindakan selesai, peneliti dan teman sejawat duduk bersama merefleksi kegiatan dari awal perencanaan sampai evaluasi. Istilah refleksi, dalam bahasa Indonesia berarti pemantulan. Refleksi adalah mengkaji atau memutar ulang secara menyeluruh tindakan yang telah dilakukan.

Adapun hal-hal yang direfleksi mencakup perencanaan pelaksanaan, kelebihan dan kekurangan. Dalam refleksi ini, peneliti dan observer melakukan evaluasi terhadap hal-hal apa yang sudah baik, dan hal-hal apa yang masih kurang atau perlu perbaikan. Terakhir membuat kesimpulan, membuat catatan apa yang harus dilakukan selanjutnya. Data hasil refleksi dijadikan acuan untuk pelaksanaan tindakan pada siklus selanjutnya.

Tindakan dianggap berhasil jika telah memenuhi indikator keberhasilan atau ketuntasan kelas sebagai berikut.

1. Ketuntasan individu, jika siswa telah mencapai nilai KKM yaitu $\geq 65$.

2. $85 \%$ dari seluruh siswa sudah mencapai nilai KKM yaitu $\geq 65$.

3. Nilai rata-rata kelas untuk kemampuan menyelesaikan soal tentang Luas Bangun Datar sudah menunjukkan angka minimal 75,00.

4. Hasil belajar afektif dan psikomotorik siswa terhadap pembelajaran melalui pendekatan kontekstual menunjukkan peningkatan (kategori baik) dengan skor $\geq 75,00$.

5. Jika sudah berjalan dua siklus, ternyata sudah mencapai poin (1), (2), (3), dan (4) maka tindakan dalam penelitian dapat ihentikan.

\section{b. Siklus II}

Seperti halnya siklus I, dan siklus II terdiri dari perencanaan, pelaksanaan, pengamatan, dan refleksi yang dilakukan berdasarkan data-data yang diperoleh pada siklus I. Hasil refleksi pada siklus I menjadi masukan pada siklus II untuk memperbaiki tindakan agar indikator keberhasilan dapat 
tercapai. Ternyata hasil pada siklus II menunjukkan penelitian harus berhenti dan tidak berlanjut ke siklus berikutnya karena indikator keberhasilan tindakan telah terpenuhi.

Tahapan ini dilakukan kembali setelah tindakan selesai, peneliti dan teman sejawat duduk bersama merefleksi kegiatan dari awal perencanaan sampai evaluasi. Yang direfleksi mencakup perencanaan, pelaksanaan, kelebihan dan kekurangan. Dalam refleksi ini, peneliti dan observer melakukan evaluasi terhadap hal-hal apa yang sudah baik, dan hal-hal apa yang masih kurang atau perlu perbaikan. Terakhir membuat kesimpulan, membuat catatan apa yang harus dilakukan selanjutnya. Data hasil refleksi dijadikan acuan untuk pelaksanaan tindakan pada siklus selanjutnya.

\section{Instrumen dan Teknik Pengumpulan Data}

Baik buruknya hasil penelitian sangat tergantung pada instrumen dan cara pengumpulan data yang dilakukan. Untuk mendapatkan data yang benar dan akurat dilakukan dengan menggunakan metode pengumpulan data sebagai berikut.

\section{a. Tes Tertulis}

Tes kemampuan tentang pola bilangan dalam penelitian ini menggunakan Penilaian Acuan Patokan (PAP) sebagai batas keberhasilan siswa. Patokan yang digunakan adalah nilai Kriteria Ketuntasan Minimal (KKM) kelas I untuk mata pelajaran Matematika yaitu sebesar 65.

Bentuk tes yang digunakan adalah tes tertulis yang diawali dengan menyusun kisi-kisi soal tes berdasarkan variabel dan indikator yang telah ditentukan.Kisi-kisi tes disusun dengan mempertimbangkan kesulitan materi pembelajaran dan waktu yang tersedia. Tes kemampuan tentang Luas Bangun Datar II dalam bentuk isian. Tes isiandiberikan untuk mengungkapkan pemahaman siswa secara menyeluruh terhadap materi yang telah diberikan.

Instrumen penilaian untuk menyelesaikan soal tentang Luas Bangun Datar pada siklus I dan siklus II diukur dengan pemberian skor seperti tertera pada tabel 3.4 dan 3.5 berikut.

Tabel 3.4 Rubrik Penilaian Siklus I

\begin{tabular}{|c|c|}
\hline Kriteria & Skor \\
\hline Jawaban benar & 2 \\
\hline Jawaban salah & 1 \\
\hline Tidak menjawab & 0 \\
\hline
\end{tabular}

Tabel 3.5 Rubrik Penilaian Siklus II

\begin{tabular}{|c|c|}
\hline Kriteria & Skor \\
\hline Jawaban benar & 2 \\
\hline
\end{tabular}




\begin{tabular}{|c|c|}
\hline Jawaban salah & 1 \\
\hline Tidak menjawab & 0 \\
\hline
\end{tabular}

\section{HASIL PENELITIAN}

Pemaparan hasil penelitian menyajikan deskripsi tentang hasil tes Luas Bangun Datar, pengamatan aktifitas siswa dan guru, serta refleksi hasil penelitian setiap siklus. Adapun hasil penelitian tindakan dari setiap siklus dipaparkan sebagai berikut.

\section{A. Pembahasan}

\section{a. Siklus I}

Hasil tindakan yang dilakukan dalam siklus I menunjukkan bahwa hasil belajar siswa dalam pembelajaran Luas Bangun Datar diperoleh nilai rata-rata kelas mencapai 67,14. Pencapaian persentase ketuntasan belajar kelas mencapai $60,71 \%$. Pencapaian hasil belajar afektif siswa sebesar $78,97 \%$. Serta $85,71 \%$ untuk pencapaian hasil belajar psikomotorik siswa.

\section{b. Siklus II}

Hasil tindakan yang dilakukan dalam siklus II menunjukkan bahwa hasil belajar siswa dalam pembelajaran Luas Bangun Datar diperoleh niali rata-rata kelas mencapai 78,56. Pencapaian persentase ketuntasan kelas mencapai $85,71 \%$. Pencapaian respon siswa sebesar $85 \%$.maka pembelajaran pada siklus II sudah berhasil atau sudah tuntas. Dengan demikian, siklus dihentikan.

Berdasarkan uraian di atas, maka dapat disimpulkan terjadi peningkatan hasil belajar, hasil belajar afektif, dan hasil belajar psikomotorik siswa dari siklus I ke siklus II. Untuk lebih jelas tentang peningkatan tersebut, dapat dilihat pada tabel 4.10 berikut.

Tabel 4.10 Rangkuman Hasil Analisis Data Siklus I dan Siklus II

\begin{tabular}{|l|l|l|l|}
\hline Siklus & Hasil Penelitian & Kriteria Keberhasilan & Keterangan \\
\hline \multirow{4}{*}{ I } & $\begin{array}{l}\text { 60.71\% (17 orang siswa mecapai KKM } \\
\geq 65)\end{array}$ & $\begin{array}{l}\geq 85 \%(24 \text { orang murid mencapai } \\
\text { KKM } \geq 65)\end{array}$ & Tidak Tuntas \\
\cline { 2 - 4 } & Rata-rata kelas mencapai 67,14 & $\begin{array}{l}\text { Rata-rata kelas mencapai } \geq \\
75,00\end{array}$ & Tidak Tuntas \\
\cline { 2 - 4 } & $\begin{array}{l}\text { Rata-rata kelas hasil belajar afektif } \\
\text { siswa 70,54 }\end{array}$ & Rata-rata kelas mencapai $\geq 75,00$ & Tidak Tuntas \\
\cline { 2 - 4 } & $\begin{array}{l}\text { Rata-rata kelas hasil belajar } \\
\text { psikomotorik siswa 75,50 }\end{array}$ & Rata-rata kelas mencapai $\geq 75,00$ & Tuntas \\
\hline \multirow{3}{*}{$\begin{array}{l}86,71 \%(24 \text { orang murid mencapai } \\
\text { KKM } \geq 65)\end{array}$} & $\begin{array}{l}\geq 85 \%(24 \text { orang murid mencapai } \\
\text { KKM } \geq 65)\end{array}$ & Tuntas \\
\cline { 2 - 4 } & Rata-rata kelas mencapai 79,96 & $\begin{array}{l}\text { Rata-rata kelas mencapai } \geq \\
75,00\end{array}$ & Tuntas \\
\hline
\end{tabular}




\begin{tabular}{|l|l|l|l|}
\hline & Rata-rata kelas hasil belajar afektif & Rata-rata kelas mencapai $\geq$ & Tuntas \\
siswa mencapai 75,89 & 75,00 & \\
\cline { 2 - 4 } & Rata-rata kelas hasil belajar & Rata-rata kelas mencapai $\geq$ & Tuntas \\
psikomotorik siswa 78,20 & 75,00 & \\
\hline
\end{tabular}

Diagram 4.1 Nilai Tertinggi, Nilai Terendah, Nilai Rata-rata Kelas, Ketuntasan Kelas, Presentase

Ketuntasan Afektif, Presentase Ketuntasan Psikomotorik Siswa pada Siklus I dan Siklus II

\section{KESIMPULAN}

Berdasarkan hasil analisis data penelitian, dikemukakan beberapa kesimpulan berikut.

1. Terjadi peningktan hasil belajar siswa Kelas V SD Negeri 101880 Tanjung Morawa tentang Luas Bangun Datar melalui pendekatan kontekstual. Nilai rata-rata kelas mengalami peningkatan dari 60,71 pada siklus I menjadi 79,96 pada siklus II. Sedangkan ketuntasan kelas mengalami peningkatan dari $60,71 \%$ pada siklus I dan menjadi $85,71 \%$ pada siklus II.

2. Hasil belajar afektif siswa Kelas V SD Negeri 101880 Tanjung Morawa terhadap pembelajaran tentang Luas Bangun Datar melalui pendekatan kontekstual adalah baik dan mengalami peningkatan dari $78,97 \%$ pada siklus I menjadi $89,28 \%$ pada siklus II. Hal tersebut menunjukkan siswa bersikap baik dan memiliki minat yang tinggi terhadap pembelajaran.

3. Hasil belajar psikomotorik siswa Kelas V SD Negeri 101880 Tanjung Morawa tentang mengenal pola bilangan dengan menggunakan media benda-benda konkritmelalui pendekatan kontekstual juga mengalami peningkatandari $85,71 \%$ pada silkus I menjadi $96,42 \%$ pada siklus II. Hal tersebut menunjukkan siswa sangat aktif mengikuti pembelajaran tentang Luas Bangun Datar.

\section{DAFTAR PUSTAKA}

Andayani. 2009. Pembelajaran Inovatif Sebagai Upaya Meningkatkan Profesionalisme Guru. Surakarta:

Pusat Pengembangan dan Pelatihan Guru Profesional (P3GP).

Anni, Chatarina Tri.2007. Psikologi Belajar. Semarang: UPT MKK Universitas Negeri Semarang

Arikunto, Suharsimi, dkk. 2009. Penelitian Tindakan Kelas. Jakarta: Bumi Aksara.

Depdikbud. 1995. Kamus Besar Bahasa Indonesia. Jakarta: Balai Pustaka.

Dimyati dan Mudjiono. 2006. Belajar dan Pembelajaran. Jakarta: Rineka Cipta bekerjasama dengan

Depdikbud.

Fathurrohman, Pupuh, dan M. Sobry Sutikno. 2007. Strategi Belajar Mengajar. Bandung: Refika Aditama

Ibrahim, R, dan Nana Syaodih. 1996. Perencanaan Pengajaran. Jakarta: Rineka Cipta. 
Fadhli, M. (2018). Internalisasi Nilai-Nilai Kepemimpinan Profetik Dalam Lembaga Pendidikan Islam. At-Ta'dib: Jurnal IImiah Prodi Pendidikan Agama Islam, 10(2), 116-127. http://ejournal.staindirundeng.ac.id/index.php/tadib/article/view/169

Murniati, Endyah. 2007. Kesiapan Belajar Matematika di Sekolah Dasar. Surabaya: 'Surabaya Intelectual Club (SIC).

Nurhadi, Senduk, A.G. 2003. Pembelajaran Kontekstual (Contextual Teaching and Learning / CTL) dan Penerapannya dalam KBK. Malang:Universitas Negeri Malang (UMPRESS).

Purwodarminto. 1998. Media-media Pembelajaran. Bandung: Refika Aditama.

Rahayu, Nina. 2013. Penilaian Hasil Proses Belajar Mengajar. Bandung: Rosdakarya.

Rusman, 2012. Belajar dan Pembelajaran Berbasis Komputer. Bandung: Alfabeta.

Sanjaya, Wina. 2007. Strategi Pembelajaran Berorientasi Standar Proses Pendidikan. Jakarta : Kencana.

Uno, Hamzah B. 2007. Profesi Kependidikan: Problema, Solusi, dan Reformasi Pendidikan di Indonesia. Jakarta: Bumi Aksara.

Zaini, M. F. (2019). The Implementation Of Learning Management In Class VIII Madrasa Tsanawiyah Islamiyah (Mts) Ypi Batangkuis. International Conference on Islamic Educational Management (ICIEM). 